\title{
Change of Land-use Patterns by Planning Field Shelterbelts on Farming Lowlands Vulnerable to Water Scarcity (Romania)
}

\author{
Iuliana VijulieA, Laura TîrlăA, Gabriela ManeaA, Elena Achim ${ }^{\mathrm{B}}$ \\ Received: March 2013 | Revised: June 2013 | Accepted: June 2013
}

\begin{abstract}
Water scarcity, drought, and land degradation are particularly serious environmental issues in Romania (south-western Boianu Plain and Olt meadow, part of theVallachian Plain). We propose a possible solution for decreasing the impact of climate change and preventing land degradation by planting shelterbelts. The main research methods approached were: direct observation, investigation method (interview), numerical methods of identifying the ecological potential of the land, selection of the appropriate species to be planted, and GIS mapping. The proposed solution isto createfield shelterbelts after a theoretical model of configuring, composing and setting them within a village areain theBoianu Plain. The lackof specialized cadastreandfunds hampers the implementation of theproject. The locals and landowners in the area must be fully aware of the importance of shelterbelts. Thus, the environmental and their living conditions would be highly improved; the effects of droughts would diminish gradually and agricultural outputgrowth. Another pending issue is to create a methodology in order to compensate the owners who disagree with the changes in land use. The area to be planted with shelterbelts is currentlythe agricultural land they own.
\end{abstract}

Key words: land degradation, aridity, planning, shelterbelts, farming lowlands, Romania

\section{Introduction}

\section{Global and regional context}

Global climate change associated with pollution, deforestation or changes in the landscape causes increasing dry process. As a result, some high-risk areas to drought tend to be affected by aridity and even desertification (loss of vegetation cover and soil degradation). The shelterbelts for fieldprotectionhave widely been used since the $20^{\text {th }}$ century as a means of defence against such climate adversities, soil protection against erosion etc.Special papers mention the greater plans to plant shelterbelts in the European lowlands, for example, Germany - the Grüner Plan; Denmark, Vienna Basin, Hungary, France, Italy, North Afri- ca (Algeria, Egypt) etc. The Roosevelt Plan conducted the planting of shelterbelts against soil erosion in the American prairie - westernUnited States (Lang, 1970). Another project aimed to initiate shelterbeltsplanting in the Canadian prairie against soil erosion and land degradation (Wark, 2006; Agroforestry Development Centre, 2010). The Greater Plan of Transforming Nature - launched in October 1948, was a project that involved the planting of a giant shelterbelts network in the southern steppes of Russia (Krech, et al., 2004), China, Australia, etc. (Byington, 1990; Mihăilă, et al., 2010).

Romania is part of the 110 countries around the world which have a number of regions prone to aridity: south and east of the Romanian Plain, Moldavi-

\footnotetext{
A Faculty of Geography, University of Bucharest, Bd. Nicolae Bălcescu, Nr. 1, Sector 1, 010041 Bucharest, Romania; iuliana.vijulie@g.unibuc.ro; tirla@geo.unibuc.ro; maneagabriela2002@yahoo.com

B Institute of Research and Forest Management (ICAS), Bd. Eroilor,Nr. 128, Voluntari, Județulllfov, Romania; nutiachim@yahoo.com
} 
an Plateau and Southern Dobrogea. The main causes are the imbalances induced both by climate patterns and the abrupt decrease of the forest vegetation in the lowlands; these have triggered frequent, long and sharp drought which presently affect the entire area (Costăchescu, et al., 2010).

In southern Romania, the situation has worsened considerablyduring the last decades with respect to forest vegetation,because of the changes in stationary conditions in the Danube Valley - land reclamation works, and because of hydro-technical facilities dams and reservoirs at Ipoteşti, Stoeneşti, Frunzaru, and Izbiceniin the Olt meadow (GD no.994/2004) ${ }^{1}$.

Lowering the groundwater level downstream the river nodes has caused the lack of moisture in the soil, which severely affected some poplar and willow forests in the floodplains.Law no.289/2002 ${ }^{2}$ on protective shelterbelts stipulates thatplanting of shelterbelts offersprotectionto agricultural land in areas frequentlyprone to drought. Thus, this action creates the prerequisites to achieve the National System of Protective Shelterbelts. The planning and rehabilitation of the shelterbelts network in the lowlands of the Mehedinți, Dolj, Olt, and Teleormancounties is the first stage in the implementation of this system -GD no. 994/2004; National Strategy on drought mitigation, prevention and combating land degradation and aridity on short, medium and long term, $2008^{3}$.

By planting fieldprotective shelterbelts,one would expect that the effects of drought on crops reduce (through the effects they generate both in winter and summer). Other positive consequences would be: avoid the effects of strong winds during summer upon the farming crops, reduce the loss of bio-accumulative horizon, prevent plants and crops uncovering and uprooting, etc. (Lupe, 1953). Reduction of the wind speed behind the shelterbelts changes environmental conditions and microclimate in the sheltered area (Neşu, 1999).In practice, the installation of shelterbelts in the Romanian Plain was an isolated initiative of the private land owners who in most cases used the Black Locust (Robiniapseudoacacia) to achieve them. They have but anextremely small share to the need for protective shelterbelts (Mihăilă, et al., 2010).

\section{Aim of the study}

The study aims to approach the issues of water scarcity, drought and land degradation in Romania, with aspecial view on the south-western Boianu Plain and the Olt Meadows, respectively Sprâncenata village. Also,

1 More details on: URL: http://www.icas.ro/DOCS/Makis/hotarare\%2onr.\%20994\%20din\%2O2004.html

2 For more see: URL: http://www.clr.ro/rep_htm/L289_2002.htm

3 The full document can be downloaded at URL: http://www.madr. ro/pages/strategie/strategie_antiseceta_update_09.05.2008.pdf it proposes a possible solution to lower the impact of climate change and prevent agricultural land degradation by planting protective shelterbelts. The main objective of this work was to develop a theoretical model for the location of protective shelterbelts network in Sprâncenata village area.

Why the Boianu Plain? The study area lies in the central-western Romanian Plain, between the rivers Olt and Vedea. It overlaps one of the areas prone to drought and aridity in the medium and long term and has a low forest cover. The climatic and agro-meteorological studies conducted during the recent years over the whole territory of the Romanian Plain highlight the intensification of the aridity phenomenon, by revealing the values of the indices for assessing the ecological potential of the Romanian Plain. The activeslope processes such as runoff and gullies that cut-off the Boianu steep face could be mitigated by planting a forest belt along the edge of the escarpment. Finally, the existence of a single irrigation channel on the field, at risk of clogging in the absence of shelterbelts, is also a strong argument in the favour of this approach.

Moreover, shelterbelts have an esthetical role in the lowland agricultural landscape, which usually is monotone and bare.

\section{Study area}

It is located in the south-western Boianu Plain and the Olt meadow (in the Olt county). Olt is one of the counties with a large deficit in forest area. Forests cover $9.2 \%$ of the county area, compared to an average of $23 \%$ at national level and $30 \%$ in the European Union (NIS, 2008). The reasons are geographical location, massive deforestation for crops and damming the Olt river (when 15,00o hectares of forest lost). Sprâncenata is one of the villages with low forest cover, located on the borderline between Boianu Plain and the Olt meadow (Figure 1). This studyonlyconcerns the eastern area of the village, in the Boianu Plain, because, unlike the meadow (sheltered by the Boianu steep face - Figure 2), it proneto prevailing winds on the westeast direction.

\section{Methodology}

The main research methods used in the study were: the method of observation, investigation method (interview), numerical methods for assessing the ecological potential of the territory, and mapping method using GIS techniques. The fieldstage included successive field trips in the local horizon of Sprâncenata village $(2010-2011)$, when situation in the field was visually, graphical and numerical assessed (direct observation, measurements of shelterbelts, field mapping, photos taking). 


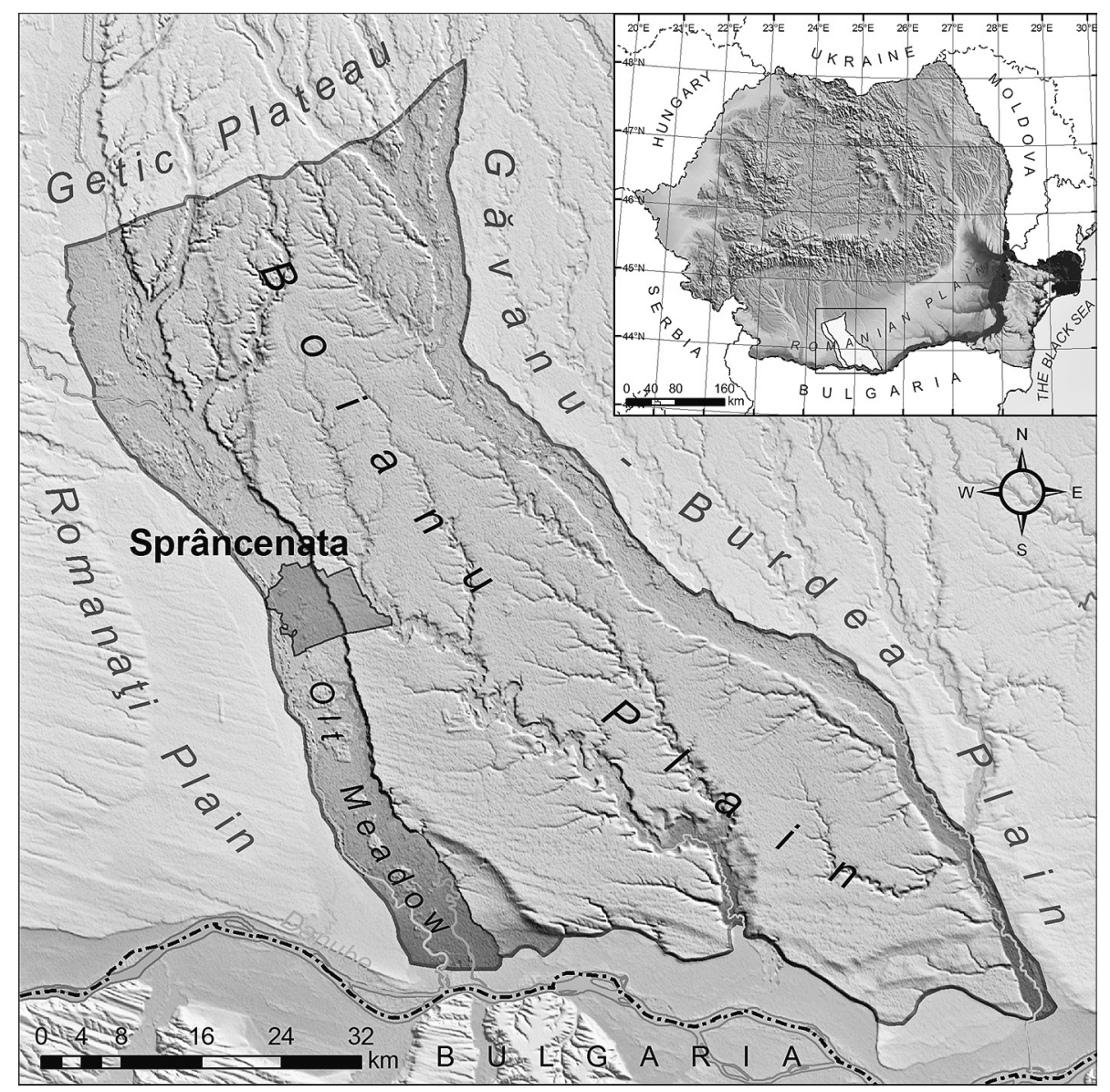

Figure 1. Geographical setting of the Sprâncenata village in the Boianu Plain and Olt meadow (SRTM30 and SRTM9o data from USGS, DEM by Laura Tîrlă)
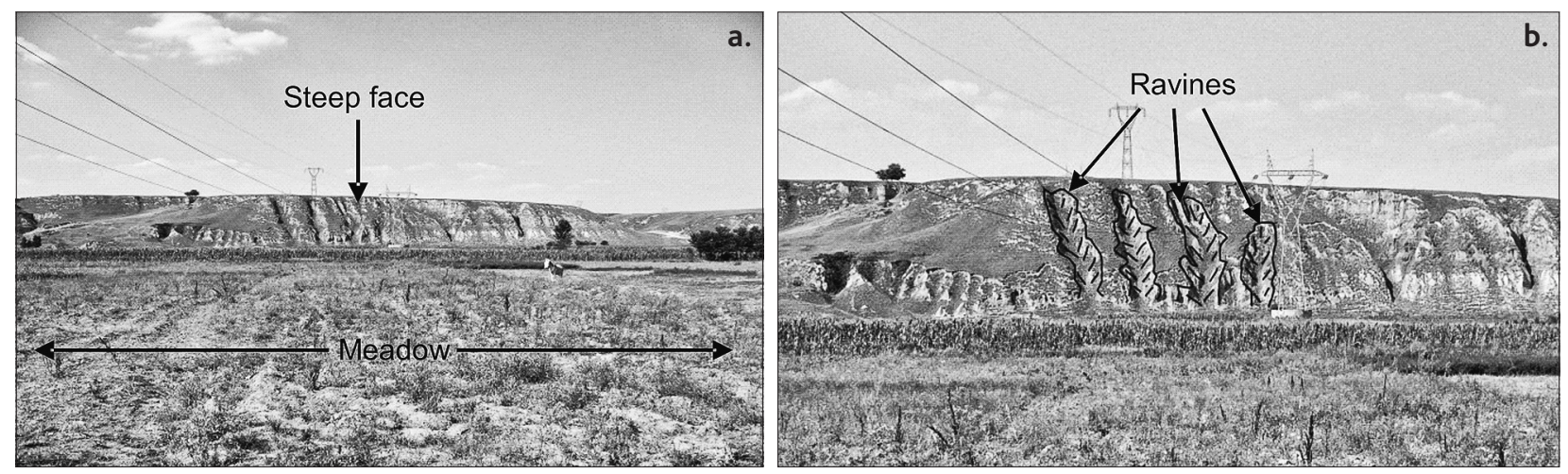

Figure 2. Landform patterns. a. The steep face of Boianu Plain towards Olt meadow. b. Gully erosion affecting the steep face (photos by lulianaVijulie, 2010, processed)

\section{Ecometric and climatic indices}

Highlighting the ecological potential of the Sprâncenata village bases on the calculation of some representativeecometric and climatic indices: fluid compensation index; precipitation amount during the accumulation of moisture in the biologically active soil horizon; precipitation amount during the maximum biological activity; de Martonne aridity index. These indiceswere used in Romania in many studies on the bioclimatic potential of different regions
(Pătroescu, 1987, 1988, 1996; Dumitraşcu, 2004, 2006; Iojă, 2006; Vijulie, 2010, etc.). The fluid compensation index $\left(I_{c h}=\Sigma \Delta P^{+} / \Sigma \Delta P\right.$, with $\left.\Delta P=P-E T P\right)$ indicates the extent to which soil moisture deficit can be compensated by precipitation (Pătroescu, 1987; Manea, 2009). The following indices: the precipitation amount during the accumulation of moisture in the biologically active soil horizon $\left(\Sigma P_{X I-I I I}\right)$ and the precipitation amount during the maximum biological activity $\left(\Sigma P_{V I I-V I I I}\right)$ are useful in assessing climat- 
ic potential favorability for developing forest species (Manea, 2009). The annual values of the de Martonne aridity index may explain the presence in a territory of the plant groups with certain water requirements.

$$
I_{a r}=P / T+10,
$$

where: $\mathrm{P}=$ annual precipitation amount; $\mathrm{T}=$ annual average temperature

The values of $\mathrm{I}_{\mathrm{ar}}<20$ units highlight an area with high moisture deficit; values between $20-25$ units are typical to areas with a medium moisture deficit (Pătroescu, 1987; Ozenda, 1994; Costăchescu, et al., 2010; Manea, 2009). The necessary climatic data (multiannual monthly average temperatures, average monthly precipitation, multi-frequency wind speed at the weather station Roşiorii de Vede in 1961-2005) was provided by the National Meteorology Agency (NMA). The Thornthwaitemethod ${ }^{4}$ was helpful in calculating the potential evapotranspiration (PET).

\section{Mapping resources and methods}

In the elaboration of the cartographic material, theworking basis was anorthophotograph from 2005 with a $0.5 \mathrm{~m}$ resolution.The orthophotographwas digitized in the ArcGIS v9.3 application (ESRI, Redlands, CA), after being georeferenced in the Stereographic projection, DealulPiscului 1970 datum (courtesy of APIA $^{5}$ ).The resulting dataset highlights the proposed sites for setting the shelterbelts. The location map was created in ArcGIS v9.x and Global Mapper v9.01 applications, as well as the processing of the SRTM data (USGS, Maryland, USA) for computing the digital elevation models (DEMs) of the Sprâncenata village area.

\section{Results and discussion}

\section{Environmental factors which condition the development of a scenario planning}

The premises of this approach in arranging shelterbelts refer to lithology and landforms, climatic conditions, hydrological potential and spontaneous vegetation. Surface deposits that influence soil formation and evolution are of Quaternary age. For this lowland, the Quaternary is at utmost importance, for the present structure of the Boianu Plain (Posea et al., 1982, p. 721; Popescu, N., 2005).

On the interfluve between the Călmățui and Olt rivers, the Pleistocene layers are made ofloess deposits which exceed $30 \mathrm{~m}$ in thickness. They maintain the

4 Details on URL: http://ponce.sdsu.edu/onlinethornthwaite. php

5 Agency for Payments and Intervention in Agriculture dusty-clayey-sandy character of the ground, making it vulnerable to wind action in the absence of a wellstructured vegetation cover. The presence of loess deposits that cover the entire field and the lack of surface water drainage from rain and melting snow have generated the processes of compaction and formation of loess sinkholes, whose presenceis critical in selecting the appropriatespecieswhich best fit the shelterbelt model (Figure 3).

The Boianu Plain rises above the Olt valley by $50-$ $60 \mathrm{~m}$, the steep slope facing west (Figure 4).The genetic soil types in the studied area belong to the Chernozems, Kastanozems and Phaeozems soils group, according to the United Nations' FAO soil classification, having humus-rich topsoils and a high base saturation. Phaeozems are dominant (Florea,Munteanu, 2012), having a dark, humus rich surface horizons that, in comparison with Chernozems and Kastanozems, are less rich in bases (FAO, 2006 ; Dănescu, et al., 2010).

The Boianu Plain in the perimeter of Sprâncenata village is a semi-endorheic basin. A few temporary watercoursesform the surface drainage network. The groundwater confines to relatively high depths (about $20 \mathrm{~m})$.

The climate of a region is critical to the nature of forest vegetation (stand composition), and with the edaphic, to the productivity levels achieved.

The vegetation map of Romania (Doniță, Roman, 1972-1979), Boianufield falls in the forest-steppe phytoclimatic zone. Both the values of the de Martonne aridity index (24.36) and fluid compensation index (0.44) synthetically show it, as well as the local topoclimate favorable to growing and spreading of grayish oak forests (Quercus pedunculiflora), downy oak (Q. pubescens), Turkey oak (Q. cerris), and flasks (Q. frainetto).

Wind is the most important factor that accelerates the evapotranspiration process. Soil water evaporation increases with wind speed, recording values up to 1o times higher than if the atmosphere would becalm.

\section{Arrangement scheme for setting a shelterbelt network in the village of Sprâncenata}

In Sprâncenata, the prevailing winds are on the west-east direction (according to climatic data of the Roşiori de Vede weather station). In accordance with the landscape features and the general orientation of agricultural plots and irrigation system, the best proposed location for setting the main shelterbelts is northwest - southeast.

Although the location of shelterbelts must consider the theoretical principles of sizing and placement of the network (orientation, distance and size), effec-

\footnotetext{
6 The document can be downloaded at: URL: ftp://ftp.fao.org/agl/ agll/docs/wsrr1oze.pdf
} 


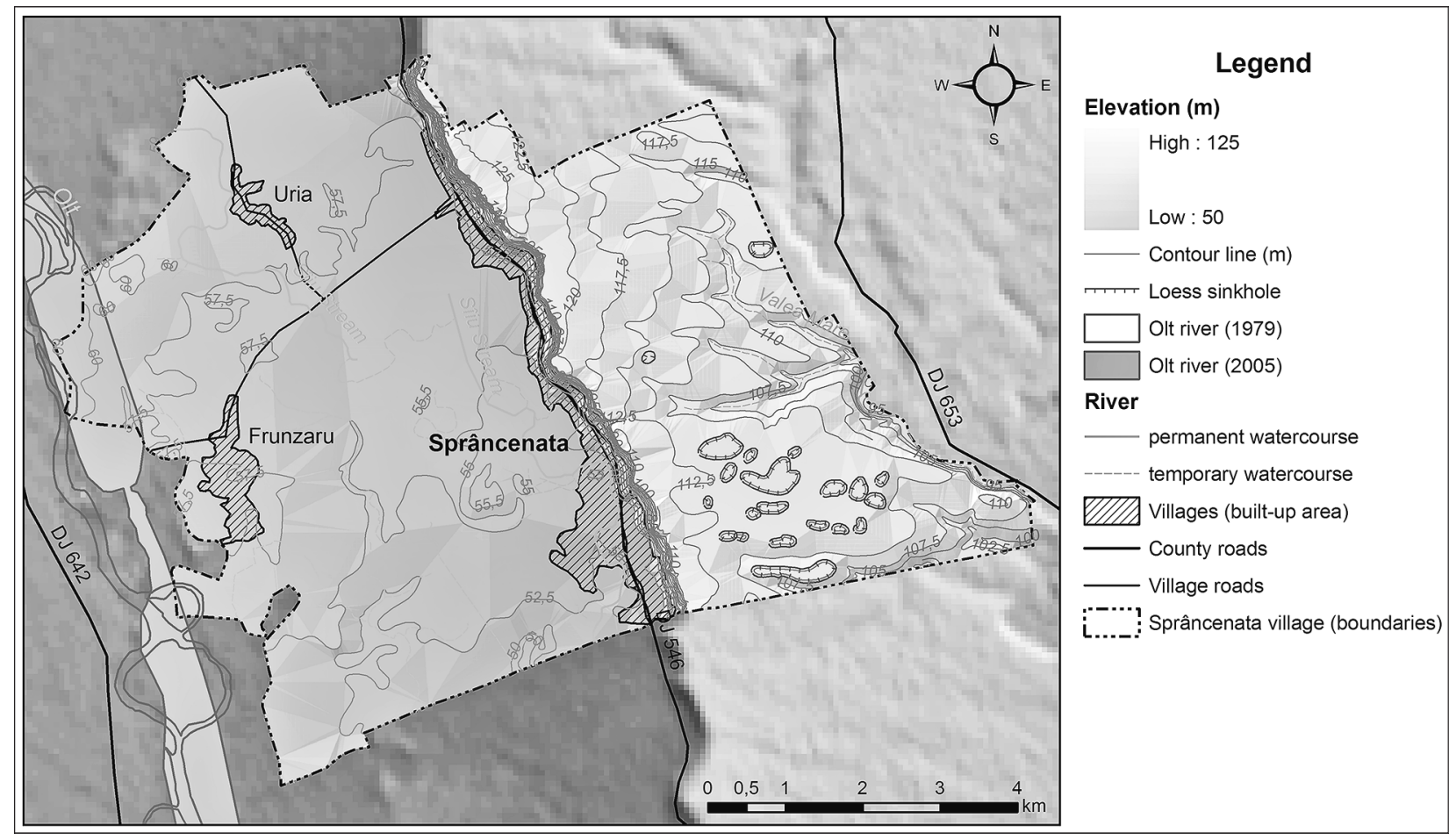

Figure 3. Physical landscape and anthropogenic features in Sprâncenata village (SRTM9o data from USGS, DEM by Laura Tîrlă)

Table 1. Valuation ratios of moisture deficit in the area of Roşiori de Vede weather station (average for period 1961-2005), after an ICAS concept

\begin{tabular}{|c|c|c|c|c|c|c|c|c|c|c|c|c|c|}
\hline & I & II & III & IV & V & VI & VII & VIII & IX & $x$ & XI & XII & Annual \\
\hline $\mathrm{T}$ & $-2,5$ & $-0,2$ & 4,9 & 11,4 & 16,9 & 20,6 & 22,6 & 22,0 & 17,6 & 11,3 & 4,9 & $-0,3$ & 10,7 \\
\hline PP & 32,0 & 31,1 & 34,5 & 41,1 & 58,2 & 61,9 & 57,7 & 42,8 & 34,9 & 29,9 & 41,9 & 38,4 & 504,4 \\
\hline ETP & 0 & 0 & 15.5 & 51.5 & 93.9 & 127 & 140.2 & 125.3 & 84.1 & 41.9 & 12.6 & 0 & \\
\hline$\Delta \mathrm{P}$ & 32.0 & 31.1 & 19 & -10.4 & -35.7 & -65.1 & -82.5 & -82.5 & -49.2 & -12 & 29.3 & 38.4 & \\
\hline \multicolumn{14}{|c|}{$\Sigma \Delta \mathrm{P}^{+}=32.0+31.1+19+29.3+38.4=149.8$} \\
\hline \multicolumn{14}{|c|}{$\Sigma \Delta \mathrm{P}^{-}=10.4+35.7+65.1+82.5+82.5+49.2+12=337.4$} \\
\hline $\mathrm{I}_{\mathrm{ch}}{ }^{* *}$ & 0.444 & & & & & & & & & & & & \\
\hline$\sum \mathrm{P}(\mathrm{XI}-\mathrm{III})$ & 177.9 & & & & & & & & & & & & \\
\hline$\sum \mathrm{P}(\mathrm{VII}-\mathrm{VIII})$ & 100.5 & & & & & & & & & & & & \\
\hline $\mathrm{I}_{\mathrm{ar}}$ & 24.367 & & & & & & & & & & & & \\
\hline
\end{tabular}

Source: The National Agency for Meteorology (ANM), 2011. $\Delta P=P-E T P ; I_{c h}=\Sigma \Delta P^{+} / \Sigma \Delta P^{-} ; \Sigma P(V I I-V I I I)=$ Sum of precipitation in the period of maximum biological activity; $\Sigma P(X I-I I I)=$ Sum of precipitation in the period of moisture accumulation in the soil; $I_{\text {ar }}=$ De Martonne aridity index $=P_{\text {annual }} / T_{\text {annual }}+10$.

tively putting their land units is subject to existing cadastral reality. Therefore, the belts usually followthe edge of the agriculturalstrip grounds and plots so as not to hamper the agricultural production process (Costăchescu, et.al., 2010, pp.37-38).

The model avoids as much as possible fragmentation of the crop lands so that the indicative distances between the belts have changed depending on local conditions. The proposed distance from the main beltis $250 \mathrm{~m}$. The side belts linkthe main ones and together form more or less regular shapes (Figure 5). The suggested distance between the side belts is $500 \mathrm{~m}$
(Costăchescu, et. al., 2010, pp.37-38). The width of the shelterbelts will be up to $10 \mathrm{~m}$ for the main belts and 8 $\mathrm{m}$ for the side belts, with a $2 \times 1$ scheme.

According to their function and importance within the belt, wood species divide into: primary or basicspecies, secondary species (mixing, stimulation species), shrubs for soil protection, and protective marginal species (thorny). Choosing of the species in order to achieve the shelterbelts makes light of the principle of promoting the indigenous naturalspecies and the bioclimatic classification of the territory. The afforestation compositions and schemespropose toa- 


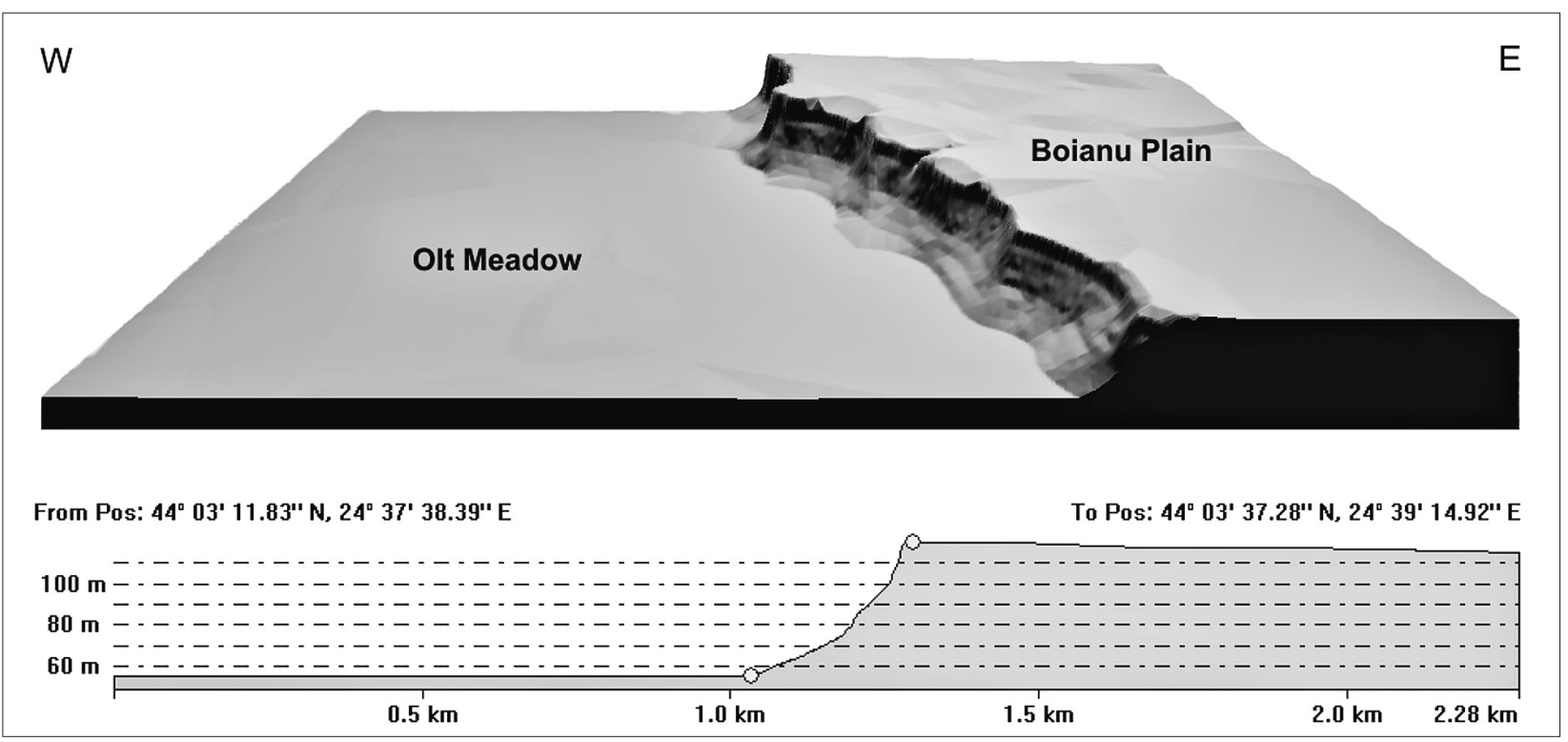

Figure 4. The escarpment of Boianu Plain facingthe Olt Meadow-3D terrain model and W-E profile (grid processed in Global Mapper v9.01 by Laura Tîrlă)

dapt the ecological requirements of the species to the ecological characteristics of the soil. It should be taken into account that, by their location in open field and the small size of the belts, the species would be forced to vegetate in conditions of increased water scarcity (Table 2; Costăchescu, et.al., 2010).

The forest species which the afforestation composition schemes base on are given in the "Technical rules of composition, afforestation schemes and technologies" -Ordinance 1648/2000 -and "Forest technical guidance for establishment, maintenance and management of forest vegetation in shelterbelts"-Ordinance $636 / 2002$.

The proposed tree species to be planted within the shelterbelts are: pedunculate oak (Quercus peduncu-

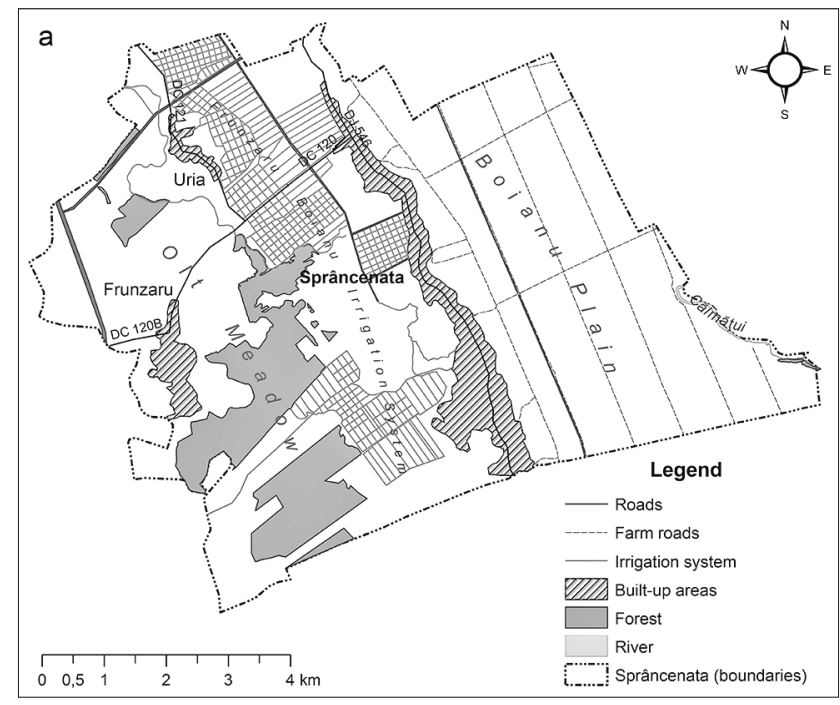

liflora), red oak (Quercus rubra) and linden (Tilia argentea). The selection is according to the present ecological requirements on these species in the Vallachian Plain and to microclimatic conditions. Artificially introduced, locust (Robinia pseudoacacia) has adapted well to edaphic-climatic conditions in the area, so it can be used as a viable alternative to the main species in the formation of field sheltering shelterbelts if the land owners wish to achieve as quickly as possible the protective effect.Species of shrubs (s) that can be used are: hawthorn (Crataegus monogyna), wild rose (Rosa canina), smoke tree (Cotinus coggygria), elder (Sambucus nigra), wild privet (Ligustrum vulgare), red thorn (Tamarix ramosissima), spindle (Euonymus europaeus), caragana(Caragana arborescens).

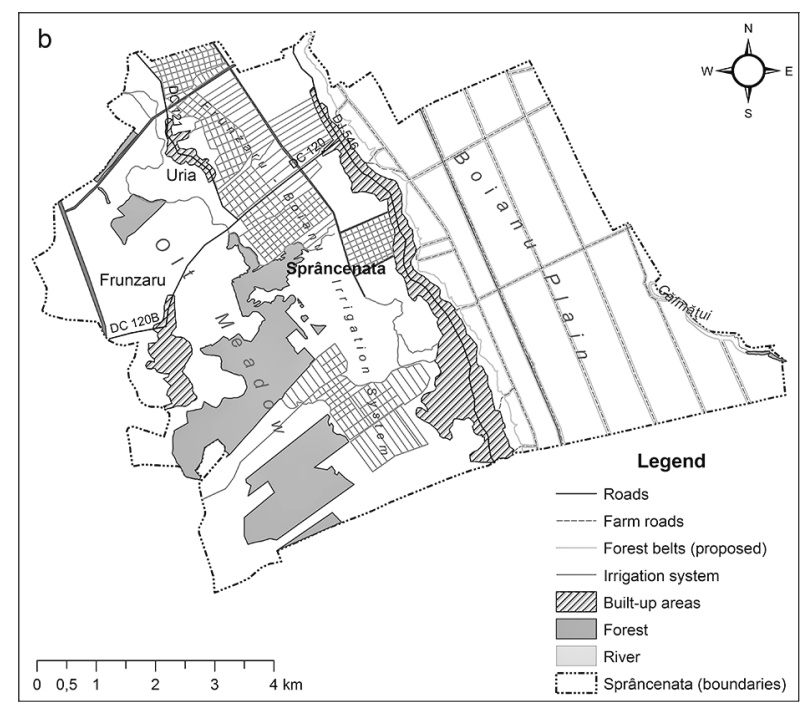

Figure 5. A theoretical model for settingfield shelterbelts in Sprâncenata village. a. Present situation (no shelterbelts); b. Proposed concept (with protective shelterbelts in Boianu Plain) 
Wild rose should be planted only in side rows, whereas privet and spindle predominantly among the interior. They have a priorityrole to protect soil and provide the necessary impenetrability for attaining the functionalpurpose of shelterbelts. Shrubs introduced among marginal and port-marginal rows will also have an esthetic, landscape function (wreath, honeysuckle, lilac, smoke tree, Forsythia etc.).

Establishing the necessary seedlings is according to areas of woodland, planting schemes and percentage of completion for each afforestation composition. Preparing the ground is one of the basic operations on which the success and development of the shelterbelts depends. The technique used depends on the landcondition and its previous use. Preparatory work to be executed consists of: cleaning the grass and woodland species (all over), grubbing plow by plowing the tractor twice (all over the area) - according to the current regulations. Forest seedlings to be used at planting will measure in accordance with STAS-sized force. Planting seedlings would be performed mechanical- and the countryside"7. This measure will help the beneficiaries to receive grants for establishing protective shelterbelts of the field. Investments of this type apply to agricultural land area of at least 0.5 hectares, which is the established value for a single forest curtain. Forest must be protected until it reaches the exploitability age, which might even be 40 . In the first year, it will provide financial support for the establishment of curtain forestry, maintenance, and compensation for loss of income. In the second, third, fourth and fifth year, the beneficiary will receive grant funds only for maintenance and for compensation for loss of income. After the fifth year since the establishment of forest curtain, the beneficiary will continue to receive just compensation for loss of income for ten years.

Concretely, for the shelterbelts planted in the plain area, the beneficiary receives $1,330 € /$ hectare, which represents $70 \%$ of the total cost $(1,900 € /$ hectare). This is the compensatory fee for establishing the shelterbelt. In the first five years, he will be paid with amounts varying between 90 and $270 € /$ hectare/year for the

Table 2. Compositions and afforestation schemes (after the ICAS standards)

\begin{tabular}{|c|c|c|c|c|c|c|c|c|c|}
\hline \multirow{3}{*}{$\begin{array}{l}\text { Composition } \\
\text { Forest steppe zone }\end{array}$} & \multicolumn{9}{|c|}{ Scheme $(2 \times 1)$} \\
\hline & \multicolumn{5}{|c|}{ Main belt } & \multicolumn{4}{|c|}{ Side belt } \\
\hline & s & Qp (Qr) & $\mathrm{Ta}(\mathrm{Ac})$ & Qp (Qr) & s & s & Qp (Qr) & $\mathrm{Ta}(\mathrm{Ac})$ & s \\
\hline \multirow{2}{*}{$\begin{array}{l}\text { Main belt } \\
40 \mathrm{Qp}(\mathrm{Qr}) 20 \mathrm{Ta}(\mathrm{Ac}) \\
20 \mathrm{Cm} 20 \mathrm{Sh}\end{array}$} & $\mathrm{Cm}$ & Qp (Qr) & $\mathrm{Ta}(\mathrm{Ac})$ & Qp (Qr) & $\mathrm{Cm}$ & $\mathrm{Cm}$ & Qp (Qr) & $\mathrm{Ta}(\mathrm{Ac})$ & $\mathrm{Cm}$ \\
\hline & s & Qp (Qr) & $\mathrm{Ta}(\mathrm{Ac})$ & Qp (Qr) & s & s & Qp (Qr) & $\mathrm{Ta}(\mathrm{Ac})$ & $S$ \\
\hline $\begin{array}{l}\text { Side belt } \\
\text { 25Qp(Qr) 25Ta(Ac) } \\
25 \mathrm{Cm} 25 \mathrm{Sh}\end{array}$ & $\mathrm{Cm}$ & Qp (Qr) & $\mathrm{Ta}(\mathrm{Ac})$ & Qp (Qr) & $\mathrm{Cm}$ & $\mathrm{Cm}$ & Qp (Qr) & $\mathrm{Ta}(\mathrm{Ac})$ & $\mathrm{Cm}$ \\
\hline
\end{tabular}

Sh (s) - shrubs; Qp, Qr - Quercus pedunculiflora, Q. rubra; Ta - Tilia argentea; Ac - Acer campestre; Cm - Crataegus monogyna; (2x1) - 2 is the distance between rows $(m)$, and 1 is the distance inside the row $(m)$.

ly. The annual review works of plantation would be executed according to instructions and rules in force. Trees will be cutting back after planting to increase the success rate in terms of precipitation deficit in the area.Until a state of massive plantation, seedlings need some maintenance: reviewing, mobilization in rows, mobilization between rows single out; spraying with insecticide solutions are needed for pest control.

\section{Conditions favouring the establishment of shelterbelts}

The Paying Agency for Rural Development and Fishing (APDRP) began in 2012 the funding for the program "Primary afforestation of agricultural land". The program would be developed under Measure 221 of the National Rural Development Programme 20072013 (NRDP), Axis II - "Improving the environment maintenance of the plantation. For another 10 years, the farmers are paid with $215 € /$ year/hectare, representing the compensation for loss of income (Measure 221).

\section{Conditions limiting the application of the afforestation schemes}

The awareness of population and landowners in the area on the importance of shelterbelts is indispensable to improve the environmental and living conditions, in order to diminish the effects of drought and increase the agricultural production (Achim, et al., 2012).

Another pending issue is to establish a methodology to compensate the owners who disagree with the change in use of the agricultural land they own and

\footnotetext{
7 More details on URL: http://www.apdrp.ro/content. aspx?item $=2101$
} 
Table 3. Selective criteria of the benefits induced by shelterbelts planting

\begin{tabular}{|c|c|}
\hline $\begin{array}{l}\text { Ecological benefits } \\
\text { (ecosystem services) }\end{array}$ & $\begin{array}{l}\text { - improvement of the microclimate; } \\
\text { - improvement of the conditions for growing and developing of adjacent crops; } \\
\text { - reduction in the slope erosion and run-off; } \\
\text { - reduction in the deflation to a halt; } \\
\text { - improvement of the conditions for soil fertility and preservation; } \\
\text { - increase in the soil moisture, soil enrichment in humus and other nutrients; } \\
\text { - changes in thepH values due to the excess of organic matter in leaves and roots; } \\
\text { - favourable conditions for the development of local microfauna; } \\
\text { - increase in the forest area; }\end{array}$ \\
\hline Economic benefits & $\begin{array}{l}\text { - increase in the production of timber; } \\
\text { - increased protection for the economic and social objectives, and communication lines; } \\
\text { - in case of exploitation, which can only be selective, benefits derive from the high quality of } \\
\text { the timber (e.g. density of } 0.95 \mathrm{~g} / \mathrm{cm}^{3} \text { for oak); } \\
\text { - shelterbelts could be some of the few timber sources in the plain area; } \\
\text { - medium- and long-term viable alternative to non-productive crop fields caused by frequent } \\
\text { drought or to non-profit crops; }\end{array}$ \\
\hline Landscape benefits & - reconstruction and esthetical improvement of the landscape; \\
\hline Social benefits & $\begin{array}{l}\text { - improvement of the people's health (thermal comfort, air purification, shadow, proper } \\
\text { mental condition, etc.); } \\
\text { - recreation function. }\end{array}$ \\
\hline
\end{tabular}

(Source: Costăchescu, et al., 2010; Achim, et al., 2012, modified).

which at the same time is on the location of the future shelterbelts (Achim, et al., 2012).

\section{Consequences of the shelterbelts planting}

According to recent conducted and published research, there are numerous positive consequences and benefits of this action (Table 3 ).

\section{Conclusions}

According to the bioclimatic conditions revealed by numerical methods for assessing the ecological potential of the analysed territory, the village of Sprâncenatabelongs to a region at risk of aridity (the Vallachian Plain), in the context of a low afforestation level.

In such conditions, increasing the forest area and implementing measures to combat drought and land degradation falls as a priority in the national strategy on prevention and control of the processes.

The proposed solution in order to mitigate the impact of climate change and prevent land degradation, is to establish by planting field protective shelterbelts as these are the most efficient windbreaks. It is also necessary to aware the population and landowners in the area on the high importance of the shelterbelts. They are able to improve the environmental and living conditions overall, to diminish the effects of droughts and increase the agricultural production.

Another pending issue is to set a methodology to compensate the owners who disagree with the change in use of the agricultural land they own. The future protective shelterbelts should be planted on this land, making at present the situation difficult and uncertain.
The most important role of the shelterbelt network in the drought affected field areas is to increase mainly the ecological and environmental quality, which indirectly leads to economic and social benefits.

\section{References}

Achim, E., Manea, G., Vijulie, I., Cocoş, O., Tîrlă, L. 2012. Ecological reconstruction of the plain areas prone to climate aridity through forest protection belts. Case study: Dăbuleni town, Oltenia Plain, Romania. Procedia Environmental Sciences 14 (2012):154-163. Doi: http://www.sciencedirect. com/science/journal/18780296.

Byington, E.K. 1990. Agroforestry in the temperate zone. In: MacDicken, K.G, Vergara N.T. (eds.) Agroforestry: classification and management. John Wiley and Sons, New York, pp. 228-289.

Costăchescu, C., Dănescu, F., Mihăilă, E. 2010. Protective shelterbelts. EdituraSilvică, Bucharest, 261 pp. (in Romanian with English summary)

Dănescu, F., Costăchescu, C., Drăgan, D. 2010. Correlation of the RomanianSoil ClassificationSystemSRCS, 1980 with the Romanian Systemof Soil Taxonomy - SRTS, 2003. EdituraSilvică, Bucharest, 80 pp. (in Romanian)

Doniță, N., Roman, N. 1972-1979. Vegetation map in the Atlas of Romania. Romanian Academy Press, Bucharest. (in Romanian)

Dumitraşcu, M., Pătroescu, M., Dumitraşcu, C. 2004. Ecometric climatic indices of the Oltenia Plain in 1961-200o. Revista Geografică, 10: 20-26. (in Romanian) 
Dumitraşcu, M. 2006. Changes in the Oltenia Plain landscapes. Romanian Academy Press, Bucharest, 229 pp. (in Romanian)

Florea, N., Munteanu, I. (eds.) 2012. The Romanian System of Soil Taxonomy. SITECH, Bucharest, 207 pp. (in Romanian)

Iojă, C. 2006. Tools andtechniques foranalysis of theenvironment quality inthe Bucharest metropolitan area. Bucharest University Press, Bucharest, 260 pp. (in Romanian)

Krech, S., McNeill, J.R., Merchant, C. (eds.) 2004. Russia and the Former Soviet Union, Encyclopedia of World Environmental History. Routledge, New York, $1077 \mathrm{pp}$.

Lang, J.B. 1970. The Shelterbelt Project in the Southern Great Plains 1934-1970 - A Geographic Appraisal. Master's thesis, University of Oklahoma, 99 pp.

Lupe, I. 1953. Shelterbelts for field protection. Series III, Technical Guide. National Publishing House, Bucharest, 88 pp. (in Romanian)

Manea, G. 2009. Indicatorsandindicesfor assessing thebioclimaticpotentialofthe DanubeGorge. Comunicări de Geografie 8, 441-444. (in Romanian)

Mihăilă, E., Costăchescu, C., Dănescu, F., Drăgoi, S. 2010. Agroforestry systems. In the Research Papers Series. EdituraSilvică, Voluntari, 189 pp. (in Romanian)

Neşu, I., 1999. Shelterbelts for field protection. Star Tipp, Slobozia, 184 pp. (in Romanian)

Ozenda, P. 1994. Vegetation of Europe.Delachaux et Niestle, Lausanne - Paris, 269 pp. (in French)

Pătroescu, M. 1987. Ecometric climatic indices and their relationship to biotic cover in the Subcarpathians between RâmnicuSărat and Buzău valleys. Annals of the Bucharest University, Geography: 8082. (in Romanian)

Pătroescu, M. 1988. On the dynamics of some ecometric indicators in the territory of Romania. Annals of the Bucharest University, Geography: 64-67.

Pătroescu - Nardin, M. 1996. The sub-Carpathians between RâmnicuSărat and Buzău valleys. Ecological potential and biological exploitation. Carro, Bucharest, 125 pp. (in Romanian)

Popescu, N. 2005. The Teleorman Plain - Landforms. In: Badea, L., Bălteanu, D., Bogdan, O., Bugă, D., Cucu, V., Donisă, I., Gâștescu, P., Iordan, I., Niculescu, Gh., Oancea, D., Posea, G., Ielenicz, M., Velcea, V., Zăvoianu, I. (eds.) The Geography of Romania, Vol. 5. Romanian Academy Press, Bucharest, pp. 189-195. (in Romanian)

Posea, G., Popescu, N., Ielenicz, M. 1982. Teleorman County. In: Posea, G. (ed.) The Geographic Encyclopedia of Romania. EdituraŞtiințificăşiEnciclope dică, Bucharest, pp. 721-722. (in Romanian)

Vijulie, I. 2010. Countryside dynamics in the Boianu Plain, Bucharest University Press, Bucharest, 325 pp. (in Romanian)
Wark, W. 2006. Prairie Farm Rehabilitation Administration. In: The Encyclopedia of Saskatchewan. Great Plains Research Centre, 1071 pp. URL: http:// esask.uregina.ca/entry/prairie_farm_rehabilitation_ administration_pfra.html (Accessed on 10-09-2011).

*** Decision 994/2004 approving the Shelterbelts Planting for Protection of the Communication Lines against Snow, published in the Official Gazette no. 648/19.07.2004. URL:http://www. icas.ro/DOCS/Makis/hotarare\%2onr.\%20994\%20 din\%202004.html (Accessed on 02-09-2011).

*** Rule 289/2002 on the Protective Shelterbelts, published in the Official Gazette no. 338/21.05.2002. URL: http:// www.clr.ro/rep_htm/L289_2002.htm(Accessed on 05-09-2011).

*** Ordinance $1648 / 2000$ on the Technical Rules of Compositions, Afforestation Schemes and Technologies, Vol. 1, Bucharest. (in Romanian)

*** Ordinance $636 / 2002$ on the Foresttechnicalguidancefor planting, maintaining and management of the forest vegetation inshelterbelt structures, published in the Official Gazette no. 104/19.02.2003. (in Romanian)

*** 2006. World Reference Base (WRB) for Soil Resources. A framework for international classification, correlation and communication. World Soil Resources Report 103, FAO, Rome. URL: ftp://ftp. fao.org/agl/agll/docs/wsrr1o3e.pdf

*** 2008. The NationalStrategyondroughtmitigation, preventionandcombatingland degradation anddesertification on short, mediumand long term. Ministry of the Environment, Bucharest. (in Romanian). URL: http://www.madr.ro/pages/strategie/ strategie_antiseceta_update_09.05.2008.pdf (Accessed on 05-09-2011).

*** 2008. Statistical data from the National Statistical Institute, Bucharest.

*** 2010. Shelterbelts - Design Guidelines for Farmyard, Field, Roadside, Livestock, Wildlife, and Riparian Buffer Plantings on the Prairies. Agroforestry Development Centre, 28 pp. URL: http:// publications.gc.ca/collections/collection_2010/agr/ A125-2-2010-eng.pdf (Accessed on 4-03-2013).

*** 2011. The Thornthwaite Method. URL: http://ponce. sdsu.edu/onlinethornthwaite.php (Accessed on 1509-2011).

*** 2011. Climatic data from the Roşiori de Vede weather station, National Agency for Meteorology, Bucharest.

*** Conservation Measure 221 on the First Afforestation of Agricultural Land - Axe II: Improvements on the Environment and Rural Space, Ministry of Agriculture and Rural Development. URL: http:// www.apdrp.ro/content.aspx?item=2101 (Accessed on 17-07-2012). 